\title{
Cervical screening in an inner city area: response to a call system in general practice
}

\author{
Katy J Shroff, Anne M Corrigan, Melinda Bosher, Mary P Edmonds, David Sacks, Dulcie V Coleman
}

\begin{abstract}
To determine whether a cervical screening call system based in general practice in a deprived inner city area would increase the numbers of women who came forward for cervical smears the response to letters of invitation for screening was monitored for one year in one general practice in the Paddington and North Kensington district of London. Women aged 20-64 were identified from the computerised age-sex register. Only $16 \%$ of these women had had a smear test. A total of 750 call letters was sent out. Initially the response was poor (57 women; $22 \%$ ), and $85(32 \%)$ letters were returned marked "address unknown." After the age-sex register was updated the response to call was 330 women $(44 \%)$. The response of women aged over 35 was better than the response of women aged 35 and under $(229(53 \%) v$ $101(32 \%))$. In the year of the study the number of women aged 20-64 on the revised register who had been screened rose by $330(14 \%)$.
\end{abstract}

A general practice based call system can improve uptake of cervical screening even in a highly mobile, socially underprivileged population.

\section{Introduction}

One of the criticisms of the family practitioner committee call and recall system for cervical cancer screening that was introduced in May 1988 is that it will not be effective in an inner city area. We evaluated this system in one general practice in a district that has one of the worst records for population mobility and social deprivation in the country.

Paddington and North Kensington Health Authority covers a small, densely populated inner city area of $11.7 \mathrm{~km}^{2}$. The population of 120400 includes all social classes, many races and cultures, and many unsettled single people and families. ${ }^{1} \mathrm{~A}$ large proportion of the population, particularly the younger age groups, is highly mobile and includes homeless people, many from ethnic minority groups, living in bed and breakfast accommodation. At any one time up to $30 \%$ of the population is not registered with a general practitioner.

In this population many women at high risk of cervical cancer have never been screened. Only $42 \%$ of general practitioners in the district take routine cervical smears at their surgeries, and most do not run an organised screening programme. This study aimed to determine whether a call system based on the age-sex register of a general practice would increase the number of women who came forward for a smear. This has not been surveyed in inner city areas, which must be reached if cervical screening is to be successful.

Mary's Hospital Medica

School, London W2 1PG

Dulcie V Coleman, MD,

reader in cytopathology

Correspondence to: Dr Shroff.

\section{Methods}

A general practice in Paddington with a computerised age-sex register but no established cervical screening service volunteered to participate in this study. A preliminary search of the records of 2903 women aged 20-64 identified those who had never had a cervical smear.

In the first two months of the study nearly one third of call letters were returned by the Post Office. It was apparent that the register had to be revised and kept up to date. After revision the register listed 2345 women aged 20-64 (1306 aged 20-35 and 1039 aged 36-64). It was not possible to establish turnover in the practice for a given year from information currently recorded either by the practice or by the family practitioner committee, but as in most inner city practices some patients on the list had moved out of the area.

Women aged 20-64 who had no record in their notes or at the laboratory of having had a cervical smear were identified from the age-sex register and were sent a letter offering them an appointment for a smear test. The letter asked them to alter the appointment if it was inconvenient or to visit during clinic hours. A simple health education leaflet about the smear test was enclosed with the letter as we thought that enough information about the procedure should be provided both to reassure the woman and to encourage uptake of the test. Women who did not respond were sent a reminder letter about two months after the call letter.

A once weekly cervical screening clinic was set up at the practice by KJS in November 1986. Cervical smears were taken by KJS or the practice nurses with an Ayre's spatula. The slides were fixed by immersion in $\mathbf{9 4 \%}$ alcohol for at least 20 minutes, and the smears were examined in the cytology department at St Mary's Hospital. All data from the screening clinic were entered on the computer, and all women were informed of their results and recall dates in writing. Women who had abnormal or unsuitable smears were sent a further appointment for the clinic with their results. Women who required colposcopy were first seen by KJS at the practice and then referred to the colposcopy clinic at the Samaritan Hospital for Women.

\section{Results}

Analysis of practice and laboratory records before the call system began showed that only $472(16 \%)$ of the 2903 women aged $20-64$ then on the age-sex register had had a smear test. Of these smears (taken from January 1981 to February 1986), 18 had been taken at the practice, 254 at local health authority family planning and well woman clinics, and the remaining 200 at antenatal clinics, outpatient and inpatient gynaecological units, and the colposcopy clinic.

From 1 November 1986, when the study was started, to 31 December 1986 a total of 262 letters were sent out. Fifty seven women $(22 \%)$ responded, and $85(32 \%)$ letters were returned marked "address unknown." At this point the register was updated.

From 1 January to 31 December 1987, 750 women 
Number (percentage) of women responding to call for cervical screening in an inner city practice, 1 fanuary to 31 December 1987

\begin{tabular}{lccc}
\hline & $\begin{array}{c}\text { Age 20-35 } \\
(\mathrm{n}=317)\end{array}$ & $\begin{array}{c}\text { Age 36-64 } \\
(\mathrm{n}=433)\end{array}$ & $\begin{array}{c}\text { Total } \\
(\mathrm{n}=750)\end{array}$ \\
\hline Women screened & $101(32)$ & $229(53)$ & $330^{\star}(44)$ \\
At clinic & $71(22)$ & $\begin{array}{c}143(33) \\
86(20)\end{array}$ & $\begin{array}{c}214(29) \\
\text { Elsewhere }\end{array} 30(9)$ \\
No response & $216(68)$ & $204(47)$ & $420(56)$
\end{tabular}

^Includes 49 women who responded to reminder letter.

were sent call letters, 434 were sent reminders, and a total of $330(44 \%)$ responded (table). Those who responded either attended the screening clinic for a smear or informed us that they had attended elsewhere for a smear as a direct consequence of the letter or that a smear had already been taken elsewhere within three years. The overall response was better in women aged 36 and over $(53 \%)$ than in women aged 35 and under $(32 \%)$. Only 49 of the 434 women who were sent reminder letters responded, of whom 36 chose to attend the clinic, the other 13 having had smear tests elsewhere.

Of the 214 smears taken at the clinic, 18 were abnormal. Atypical cells were found in six smears obtained from women aged 23-45. The 12 smears that showed cervical intraepithelial neoplasia were obtained from women aged 21-49, 11 of whom were referred for colposcopy.

\section{Discussion}

The family practitioner committee's age-sex register, an integral and essential part of the call and recall system, is compiled from information sent to the committee by the practices and is therefore only as reliable as the register or records at the practice. Under the new arrangements for cervical screening, call letters generated by the family practitioner committee are sent to general practitioners to be checked against their registers or records before being sent to the patients. Accurate records are thus essential. While making additions to and deletions from the list we found common errors such as men entered as women, incomplete or non-existent addresses, and inaccurate dates of birth.

After our age-sex register had been revised response to call for cervical screening improved. After one year the number of women who had been screened had increased by $330,14 \%$ of the 2345 women of screening age. Of these 2345 women on the revised register, 750
(32\%) had been sent call letters. Allowing for problems and delays in setting up a call system, primary call for the women of screening age presently registered with the practice would take about three years.

Most women who responded did so to the first call letter, and most kept their original appointment. A better overall response was obtained in older women (aged over 35) than in younger women. The positive response to a specific invitation for a smear, especially among older women, corresponds with the findings of Wilson and Leeming. ${ }^{2}$

The poor response to reminder letters is disturbing. After the age-sex register was updated only 10 letters were returned by the Post Office, so there is good reason to believe that the letters were being received by these women. Non-attendance could be due to anxiety about the smear test, fear of cancer, or personal beliefs and circumstances. ${ }^{3}$ Several suggestions of how to reach these women have been put forward, including a register of non-responders at the practice and a system of flagging patients' notes to allow women to be approached about screening when they next come to the practice. ${ }^{3}$ Personal home visits by health visitors or district nurses could be helpful but are time consuming and costly.

Whatever the response to a family practitioner committee's call and recall system, it does not address the problem of women not registered with a general practitioner, many of whom are highly mobile and homeless. They would have a smear only if they attended a family planning clinic, an antenatal clinic, or a gynaecological or special clinic. They might be reached through health visitors who refer them to family planning and well woman clinics. Women's groups, which some of the unregistered women may attend, could also be a way of providing information that would lead to self referral to local health authority clinics. Although there are problems of reaching certain populations of women, even in an inner city area such as Paddington and North Kensington a properly coordinated call system can reach women of all ages.

We thank Laura Sullivan for her help with the computer.

1 Office of Population Censuses and Surveys. Mid year estimates 1986. OPCS Monitor 87/1. (Series PP1)

2 Wilson A, Leeming A. Cervical cytology screening: a comparison of two call systems. Br Med f 1987;295:181-2.

3 Nathoo $\mathrm{V}$. Investigation of non-responders at a cervical cancer screening clinic in Manchester. Br Med f 1988;296:1041-2.

(Accepted 31 August 1988)

\section{ANY QUESTIONS}

Is the asbestos used in some vehicle drum brakes a hazard to mechanics working on them?

The hazards of asbestos products differ according to the type of asbestos used. Put simply, blue asbestos may cause mesothelioma or asbestosis while white asbestos (chrysotile) may cause asbestosis. These effects seem to be dose related. Lung cancer may be a complication of asbestosis, particularly in smokers. Because the shorter fibres are more readily ingested by macrophages it is generally considered that the longer fibres ( $>5 \mu \mathrm{m}$ long) are the hazardous ones.

Brake material might contain about $30 \%$ by weight of chrysotile, although the heat of friction may convert most to the non-fibrous fosterite. Thus in several electron microscope studies brake drum dust showed an asbestos content of less than $1 \%$ by weight. Furthermore, the longer fibres get broken down and chrysotile fibres of more than $5 \mu \mathrm{m}$ form less than $1 \%$ of the total. A German study, taking into account the frequency of different jobs and the exposures that they give rise to, concluded that fibre concentrations, typically 0.01 fibre/ml, were well below the German standard of $1.00 \mathrm{fibre} / \mathrm{ml}$. These standards are set to prevent the appearance of early asbestosis, a word that a recent leader in the British fournal of Industrial Medicine suggests "has to be deprived of its macabre meaning and its grim implications." 3

Blue asbestos is quite different, but it was used only for a short time many years ago for the manufacture of friction materials. Cases of mesothelioma after such use have been described but may be regarded as rarities.

Dust should be removed not by blowing but by vacuum, ensuring that the texture of the bag is such as to remove asbestos fibres and not permit them to recirculate. -W R LEE, formerly professor of occupational health, Manchester

I Rodelsperger K, Jahn H, Brucke B, Manke J, Paur R, Woltowltz H-J. Asbestos dust exposure during brake repair. Am f Ind Med 1986;10:63-72.

Morgan WKC, Seaton A. Occupational lung diseases. London: W B Saunders, 1984:329.

3 Beritic T. Benign asbestosis: words and thoughts. Br f Ind Med 1988;45:433-4. 